\title{
VISUAL STORYTELLING E PESQUISA-FORMAÇÃO NA CIBERCULTURA
}

\section{TANIA LUCÍA MADDALENA}

Universidade do Estado do Rio de Janeiro

- CARINA D'ÁVILA

Universidade do Estado do Rio de Janeiro

\section{EDMÉA SANTOS}

Universidade do Estado do Rio de Janeiro

RESUMO Imagens, narrativas e sons permeiam nosso cotidiano desde sempre; suas formas e meios de difusão foram mudando ao longo da história da humanidade. Narramos histórias orais, nas pedras das cavernas, no livro impresso, no rádio, no cinema, na televisão e hoje por meio de todo tipo de tela. A hipermídia é a linguagem da cultura contemporânea e nos inspiramos nos seus fenômenos narrativos para pensar e criar as práticas pedagógicas. Partindo desse contexto, o presente artigo apresenta uma pesquisa-formação desenvolvida no ano 2015, na disciplina Tecnologias na Educação do curso de Pedagogia da Universidade do Estado do Rio de Janeiro, UERJ, na qual o Visual Storytelling (narração visual de histórias), na rede social Instagram, foi um dos gêneros trabalhados como proposta pedagógica da formação de professores. Mediante a arte de lembrar, as professoras em formação trouxeram suas recordações da escola, materializadas em narrativas e imagens digitais, lançando novos olhares sobre os artefatos tecnológicos da infância. Neste artigo, revolvemos, a ideia da potência das hiperescritas de si, no processo de formação docente.

Palavras-chave: Visual Storytelling. Fotografia. Pesquisa-formação. Formação de professores.

\section{ABSTRACT VISUAL STORYTELLING AND RESEARCH-TRAINING IN CYBERCULTURE}

Images, narratives and sounds have permeated our daily life ever since, its forms and means of diffusion have been changing throughout the history of humanity. We narrate oral stories, on cave stones, in the printed book, on the radio, in the movies, on television and 
today through all kinds of screens. Hypermedia is the language of our contemporary culture and we are inspired by its narrative phenomena to think and create pedagogical practices. From this context, the present article presents a research-training developed in 2015, in the discipline Technologies in Education for the course on Pedagogy of the University of the State of Rio de Janeiro, UERJ, in which Visual Storytelling through the network Social Instagram, was one of the genres worked as a pedagogical proposal in teacher training. Through the art of remembering, the teachers, in training, brought their memories of the school materialized in narratives and digital images with new looks on the technological artifacts of childhood. In this article, we turn, finally, the idea of the potenciality of the self-writting in the process of teachers training.

Keywords: Visual Storytelling. Photography. Research-training. Teacher training.

\section{VISUAL STORYTELLING E INVESTIGACIÓN-FORMACIÓN} EN LA CIBERCULTURA

Imágenes, narrativas y sonidos permean nuestro cotidiano desde siempre, sus formas y medios de difusión fueron cambiando a lo largo de la historia de la humanidad. Narramos historias orales, en las paredes de las cavernas, en los libros impresos, en la radio, en el cine, en la televisión y hoy a través de todo tipo de pantallas. La hipermedia es el lenguaje de nuestra cultura contemporánea y nos inspiramos en sus fenómenos narrativos para pensar y crear las prácticas pedagógicas. Partiendo de este contexto, el presente artículo presenta una investigación-formación desarrollada en el año 2015, en la disciplina Tecnologías en la Educación del curso de Pedagogía de la Universidad del Estado de Río de Janeiro, UERJ, en la cual la práctica de Visual Storytelling (narración visual de historias) en la red social Instagram, fue uno de los géneros trabajados como propuesta pedagógica en la formación de profesores. Mediante el arte de recordar, las profesoras en formación, trajeron sus memorias de la escuela materializadas en narrativas e imágenes digitales con nuevas miradas sobre los artefactos tecnológicos de la infancia. En este artículo, traemos finalmente, la idea potente de los hiperrelatos autobiográficos en el proceso de formación docente.

Palabras clave: Visual Storytelling. Fotografia. Investigación-formación. Formación de profesores. 


\section{Visual Storytelling: ${ }^{1}$ imagens e histórias nas redes}

0 relato não exprime uma prática.

Não se contenta em dizer um movimento. Ele o faz.

Michel de Certeau (2012, p. 145)

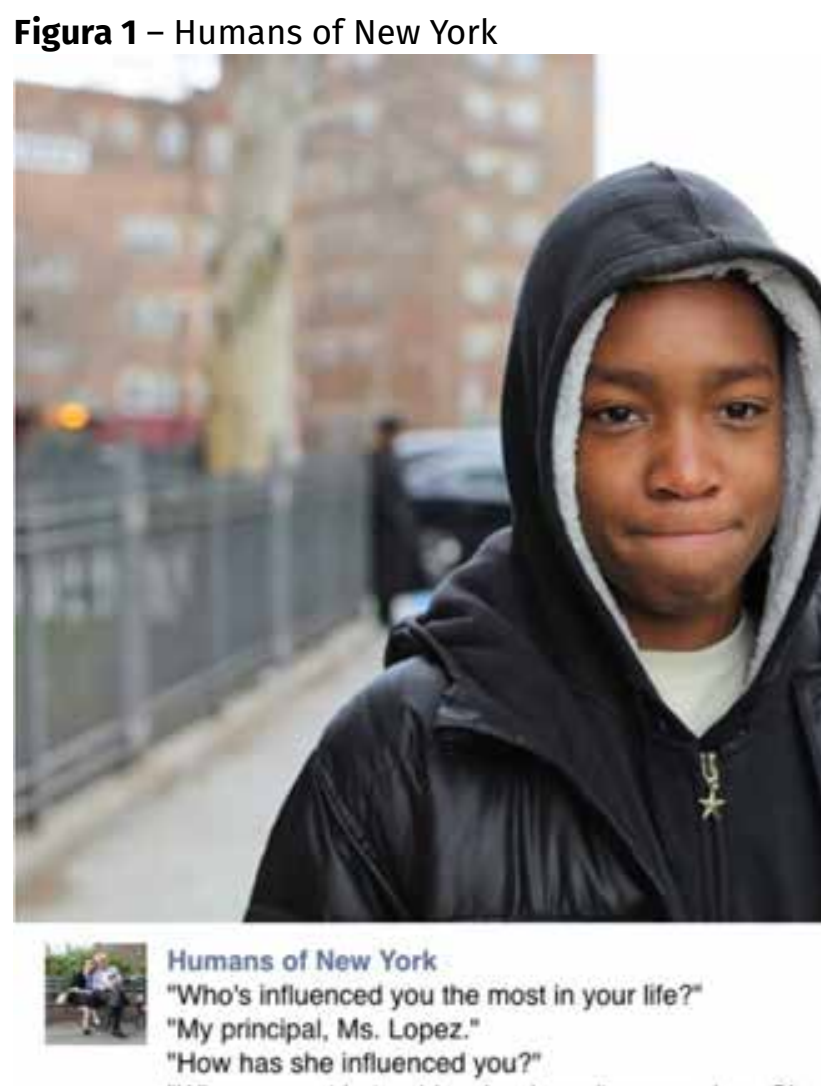

Fonte: Facebook de Humans of NY.

O fotógrafo americano Brandon Stanton, criador de Humans of New York, ${ }^{2}$ um projeto fotográfico de amplo impacto social nos Estados Unidos, publicou a fotografia acima, em sua página de Facebook, no dia 19 de janeiro do 2015. A história da vez era de Vidal, um adolescente da periferia de Nova York, que respondia que a pessoa que mais influenciava a vida dele era a diretora da sua escola: Ms.

1 Esse trabalho conjunto vem sendo aprofundado, há aproximadamente dois anos, quando entrelaçamos pesquisas e criamos a oficina de Visual Storytelling, já ministrada em alguns congressos de Educação e novas tecnologias. Para saber mais, disponível em: <http://historiasvisuais.blogspot.com.br>.

2 Disponivel em: <http://www.humansofnewyork. com/>. Acesso em: 11 jul. 2017.
Lopez, pois, em situações de apuros, ela não os expulsava da escola, prática comum no sistema educacional americano para a resolução de conflitos. Diferentemente, ela assumia uma outra posição, talvez mais acolhedora, e explicava para cada estudante como a sociedade era construída de maneira desigual e se eles saíssem da escola uma nova cela de cadeia seria construída ao redor deles. Dizia ainda que, para ela, cada um dos estudantes importava, por isso refletia com eles o papel de cada um nesse sistema.

Essa história se espalhou pelas redes sociais de tal maneira que a escola ficou conhecida e passou a receber apoio e doações de diversas instituições americanas. Ms. Lopez também foi fotografada e entrevistada por Brandon e, dado o impacto na história da escola pelo trabalho que Ms. Lopez fazia com os alunos, na periferia de NY, no dia 5 de fevereiro de 2015, os três (Vidal, Ms. Lopez e o fotógrafo Brandon) foram chamados pelo presidente dos EUA, Barack Obama, para conhecê-los, parabenizá-los. Evidentemente, tiraram uma fotografia juntos.

Trouxemos essa história para começarmos a pensar sobre as potencialidades da Visual Storytelling na cibercultura, histórias narradas mediante fotografias e imagens, nas redes virtuais da Internet. Exemplos como o projeto fotográfico Humans of New York, composto por imagens fotográficas e breves relatos de vida dos personagens das fotos, habitantes da cidade de Nova York, nos demonstram esse movimento dialógico entre as cidades e as redes sociais virtuais na internet, nas quais as histórias circulam, mobilizam afetos, possibilitam reinterpretações e formações diversas.

O projeto Humans of New York utiliza a metodologia de fazer perguntas sobre questões da vida, aos diversos cidadãos que circulam pela cidade e, assim, cria a composição de uma narrativa e uma imagem fotográfica - o que foi 
um sucesso nas redes sociais. Hoje, esse projeto se expandiu para várias capitais do mundo; inspirados na ideia do fotógrafo Brandon Stanton, encontramos Humans of London, $\mathrm{Hu}$ mans of Buenos Aires, Humans of São Paulo, entre outros.

A Storytelling, narração de histórias, ${ }^{3}$ é uma prática ancestral. Nós sempre contamos histórias de diversas maneiras e meios, o que foi constituindo a história da humanidade. No seu livro Realidade mental e mundos possiveis (1998), Jerome Bruner contrapõe duas modalidades de funcionamento do pensamento: a lógico/científica e a narrativa. A primeira está regida por hipóteses e princípios, utiliza a categorização e a não contradição nas conexões formais, e é o modo pelo qual resolvemos as questões burocráticas da vida. A segunda, conhecida como modalidade narrativa do pensamento, ocupa-se das ações humanas, constituindo, segundo o autor, a forma de pensamento mais antiga da humanidade. Esse pensamento consiste em contar histórias de si para si mesmo e para os outros. Ao narrar essas histórias vamos construindo significados através dos quais nossas experiências vão adquirindo novos sentidos, pois cada modalidade de pensamento permite modos caraterísticos de acesso à realidade.

Assim, para Bruner (1998), o lugar da narrativa na vida da sociedade é central. Este autor afirma que vivemos a maior parte das nossas vidas em um mundo construído sob as regras e mecanismos da narração e isto significa que todos, de algum modo, experimentamos a arte de narrar.

A cibercultura, a cultura contemporânea, cria novas relações entre a técnica e a vida social. O desenvolvimento da hipermídia e a liberação do polo de emissão possibilitaram

3 O termo Story em português significa estória (narrativa de ficção, oral ou escrita), mas, na tradução do termo escolhemos o uso da palavra história, porque partimos da ideia de que estória e história são partes indivisiveis de um mesmo processo, na Storytelling, onde ficção e realidade se complementam no ato de narrar. não somente uma nova maneira de contar histórias, como também de compartilhá-las e difundi-las em rede, diversificando, assim, novas formas de narrar. Neste contexto, surgem novos espaçostempos ${ }^{4}$ mediados pelas tecnologias digitais em rede, nos quais muitas práticas de aprendizagem e autoria são criadas e desenvolvidas.

Nossa intenção é mostrar como a Storytelling se apresenta com novas caraterísticas na cibercultura. Assim, podemos encontrá-las nas estratégias de marketing das grandes empresas, na publicidade, ONGs, instituições educativas, e nas produções de milhões de pessoas que habitam e publicam conteúdo nas redes sociais da Internet. Narrar e contar histórias pessoais, na linguagem da hipermídia, produz efeito marcante no praticante cultural que cria e também interage com essas histórias.

Diante de um computador, tablet ou smartphone, cada um de nós registra sua história via redes sociais, narra o que está vivendo, testemunhando ou inventando, o que quiser. Milhões de milhões de histórias lutando por um lugar ao sol na bombardeada memória das pessoas, buscando ser lembradas, admiradas, compartilhadas. Histórias de indivíduos, grupos, nomes e marcas, tudo misturado. (XAVIER, 2015, p. 15)

Na diversidade de histórias narradas no cotidiano das redes que habitamos no ciberespaço, podemos observar como as lembranças e as memórias constituem parte da formação pessoal e as histórias de vida se manifestam como fontes fundamentais na construção de saberes. A arte do lembrar, com todo o seu potencial, é evocada por diversos espaços on-line e redes sociais, como Facebook, por exemplo, quando traz nossas antigas "memórias" e

4 Esse modo de escrever este e outros termos foram "ensinadosaprendidos" com Alves (2015), como "dentrofora", "espaçostempos", "aprenderensinar" etc. devendo-se à compreensão de que, na modernidade, a ciência foi criada por dicotomias, sendo imprescindivel a superação de tais concepções, por entendermos a indissociabilidade dos mesmos. 
"acontecimentos", em fotografias e narrativas de anos passados, para a nossa timeline. Ou quando faz um minivídeo automático recopilando "os melhores momentos" ou "o aniversário de uma amizade próxima", sempre trazendo, mediante algoritmos, nossas lembranças.

Não é somente a rede social Facebook que possui essas potencialidades, mas existem outras redes sociais e aplicativos que podem ser utilizados hoje para narrar histórias e criar Storytelling com fotografias. O Instagram ${ }^{5}$ é uma rede social on-line de compartilhamento de fotos e vídeos entre seus usuários que permite aplicar filtros para editar as imagens. 0 app, criado em 2010, suporta imagem, texto, vídeos, mapa de localização e hashtags e é uma das redes sociais que mais se expandiu nos últimos anos, dando prevalência a um conteúdo mais imagético. É comumente escolhida também por muitos Storytellers, contadores de histórias, profissionais dedicados à prática do fotojornalismo, publicitários, fotógrafos e artistas, como interface para denunciar, informar e narrar suas crônicas de viagens e histórias.

Figuras 2 e 3 - Logo do Instagram

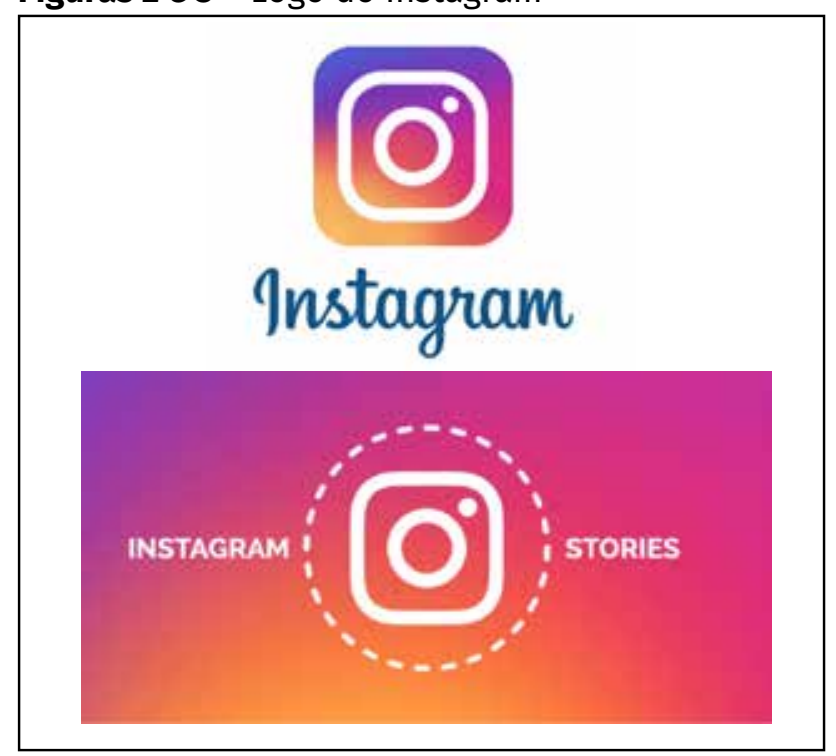

Fonte: Site oficial da rede social Instagram.

No final de 2016, o Instagram incorporou a opção de contar histórias, Instagram Stories

5 Intagram. Disponível em: <https://www.instagram. com/>. Acesso em: 10 jul. 2017. (imagem 2), que permite, por meio de vídeos curtos e imagens com pequenos textos, emoticons e efeitos, a narração curta de histórias, que 24 horas depois se autodestroem, somem, dando prioridade a uma espontaneidade na qual nada é permanente, o mesmo estilo de vídeos que inaugurou a rede social Snapchat.

Essa possibilidade da opção Stories confirma que, de alguma maneira, a Digital Storytelling está em expansão e que cada vez mais é utilizada pelos praticantes culturais ${ }^{6}$ nas diversas redes sociais da Internet. Eles contam histórias prioritariamente através de fotografias e vídeos, criando Visual Storytellings efêmeras. As próprias interfaces de outras redes sociais como o Facebook e o Whatsapp, também têm incorporado a opção Stories, desde 2017. Embora a opção de contar histórias não estivesse disponível no Instagram, em 2015, nós já tínhamos a impressão de que era possivel utilizar essa plataforma como um potente espaço narrativo.

Entendemos assim, a Visual Storytelling como um dos gêneros da Storytelling na cibercultura, essa modalidade de narrar conjugando e mixando imagens e narrativas breves é uma composição autoral que os usuários utilizam. Não são meras legendas ou rodapé nas imagens, é uma composição que vai além da descrição, contando uma história e trazendo momentos e singularidades na descrição que, de alguma maneira, incorporam os elementos e componentes de uma história (personagens, trama, conflito etc.), seja da vida pessoal, uma ficção ou invenção do narrador.

Além do Instagram, existem outros App específicos para Storytelling com imagens, como o Steller um aplicativo que também funciona como rede social, mas permite a criação de ál-

6 Nas pesquisas com os cotidianos escolares (ALVES, 2008a; 2015; OLIVEIRA, 2012) é assumida a noção de "praticante cultural", que escolhemos adotar, no presente artigo, entendendo os sujeitos como atores/atrizes dos seus cotidianos, valorizando as práticas, criações, operações culturais diárias do sujeito comum.

7 Steller. Disponivel em: <https://steller.co/>. Acesso em 11 jul. 2017. 
buns de fotografias com a incorporação de texto; esses álbuns contam histórias de lugares, viagens e variadas experiências. Os usuários podem ter acesso direto à capa do álbum e percorrer a história em forma de livro fotográfico, composto de até 10 imagens.
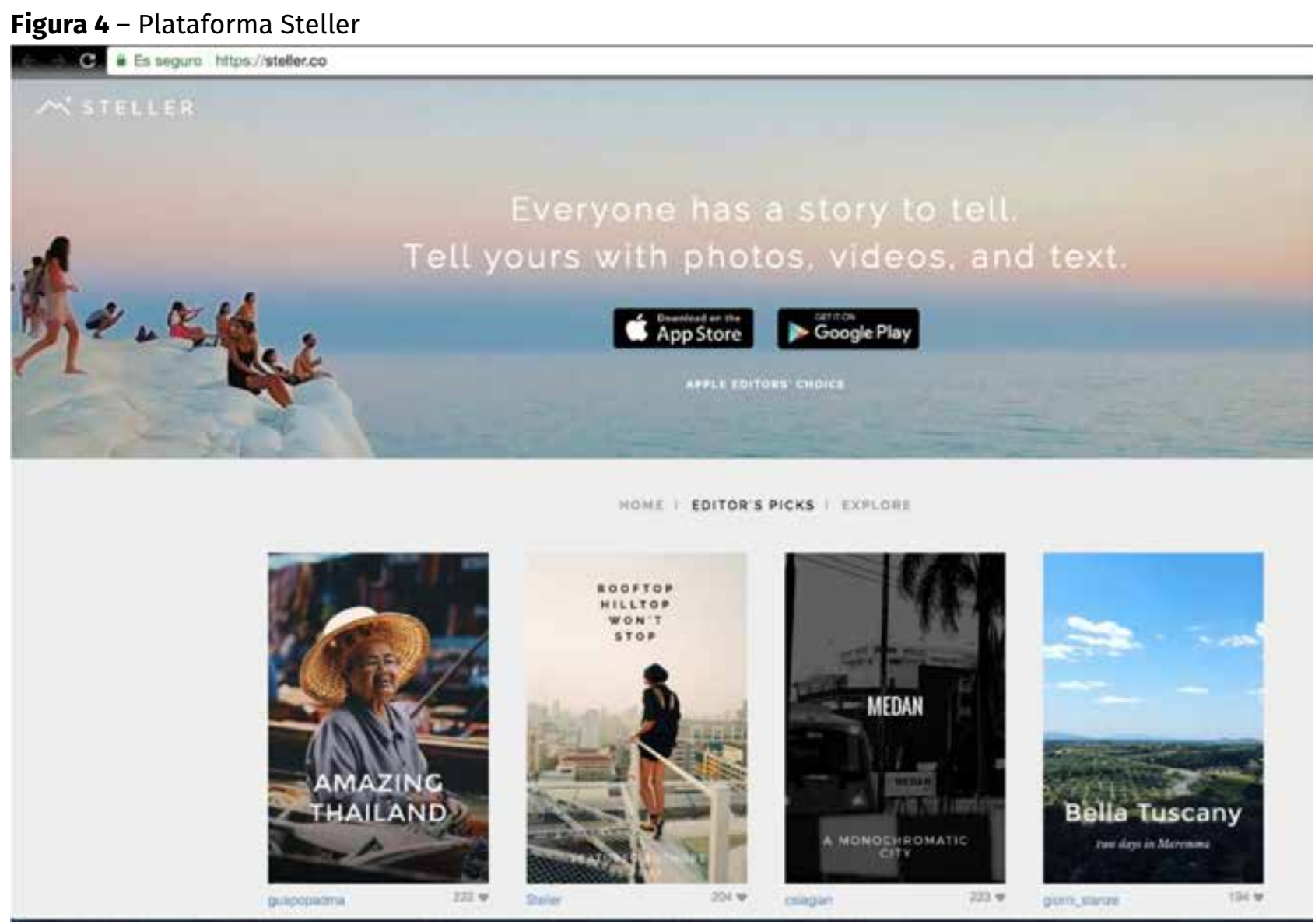

Fonte: site web Steller.

Além de aplicativos como o Steller, também há plataformas que funcionam como repositórios de histórias pessoais, como o caso do portal Cowbird,8 que começou como uma rede social, porém parou de funcionar como tal, hoje é chamada de "biblioteca pública da experiência humana". A primeira intenção desta rede social, lançada no ano de 2012, era que os usuários pudessem contar suas próprias histórias, utilizando fotos, textos e sons, ou misturando todas essas linguagens. Além das histórias pessoais, na colaboração com outros usuários, era possivel publicar histórias coletivas sobre temas e assuntos que o grupo de usuários tenha vivido e, assim, dar uma visão

8 Cowbird. Disponível em: <http://cowbird.com/>. Acesso em: 11 jul. 2017. mais ampla ao acontecimento vivido e narrado de maneira coletiva.

Repositórios como o Cowbird nos inspiram e mostram como a Visual Storytelling tem ganhado espaço nas práticas culturais dos usuários, na cibercultura, e a cultura imagética potencializa-se com o uso dos dispositivos móveis, com câmeras fotográficas. O compartilhamento de histórias pessoais sobre diversos assuntos, utilizando fotografias para serem narradas é o que caracteriza esses espaços. Hoje encontramos neste repositório histórias de superação, de nascimentos e mortes, de descobertas, de viagens, de enganos e mistérios, sempre falando a partir de uma perspectiva pessoal, enaltecendo a experiência humana, com todos seus defeitos e virtudes. 


\section{Pesquisa-formação na cibercultura}

Cristina D'Ávila (2008), ao abordar os paradigmas de formação docente, identifica a "epistemologia das práticas" como um novo paradigma de formação, na contemporaneidade. Reconhecemos a pertinência deste paradigma para a compreensão da metodologia pesquisa-formação, já que:

A epistemologia da prática busca o reconhecimento de um saber oriundo, mobilizado e reconstruído nas práticas docentes. Busca compreender e elucidar a produção de saberes no bojo da experiência docente - saberes subjetivos que se objetivam na ação. A noção de saber assumida engloba, num sentido amplo, os conhecimentos, as competências, habilidades e atitudes ou o que convencionamos chamar de saber, saber fazer e saber ser. Ao que acresço a dimensão do saber sensível, vinculado à experiência estética e lúdica. Esses tipos de conhecimento, diferentemente das representações em estado inconsciente, refletem o que os profissionais dizem de seus próprios saberes profissionais. Nesses estudos, interessa saber como os professores integram esses saberes a suas práticas, os produzem, transformam e os ressignificam no seio do seu trabalho. (D'ÁVILA, 2008, p. 33-34)

Uma pesquisa-formação não dá voz ao outro, nem tem acesso à compreensão do outro. Lançamos mão de dispositivos, que têm a função de disparar o movimento da pesquisa-formação, na criação do desenho didático das nossas práticas formativas e os criamos em conjunto, por docente e estudantes, visando à produção de conhecimentos e à reestruturação de sua prática (NÓVOA, 2004). Esses dispositivos são, na verdade, táticas (CERTEAU, 2012) singulares que os sujeitos desenvolvem em seu cotidiano, para lidar com os dilemas vivenciados em sua docência. A partir desses dispositivos, narrativas, imagens e sons emergem como fruto de autorias e coautorias do processo formativo, vivenciado pelos atores da pesquisa.

O pesquisador, portanto, não tem acesso direto à compreensão do outro. 0 rigor dos seus métodos porta esta premissa, e como tal, constrói dispositivos capazes de trabalhar com a intenção e as escolhas dos atores sociais, único caminho rigoroso que pode possibilitar alguma aproximação da compreensão do outro e da sua realidade, com isso, produzir o que se denomina nas epistemologias qualitativas de conhecimento situado. (MACEDO, 2009, p. 88)

Na pesquisa-formação, é vital entender a prática docente, para além da racionalidade técnica, como uma fonte de conhecimentos e lugar privilegiado para fazer pesquisa. Aqui reside um dos maiores desafios de optar pela ciberpesquisa-formação, ou pesquisa-formação na cibercultura. As práticas formativas nos espaçostempos da cibercultura articulam-se ao próprio movimento das redes, da mobilidade e ubiquidade dos dispositivos móveis, das experiências de leitura e escrita na hipermídia. Práticas que mudam, que inovam e inspiram novas práticas, essa é a dinâmica que caracteriza nosso tempo. Com esse desafio, lidamos no cotidiano do nosso campo, fazendopensando práticas formativas na cibercultura, o que implica a imersão e a utilização das tecnologias digitais como artefatos culturais das práticas.

A disciplina Tecnologia Educacional faz parte das disciplinas obrigatórias do primeiro período do curso de Pedagogia, e isso não é um dado menor. Os alunos que chegaram ao nosso encontro estavam começando o curso, conheciam pouco a UERJ, seus colegas e a vida universitária. Isto se apresentava como um grande desafio, já que, além dos conteúdos curriculares próprios da área da Tecnologia Educacional que desejávamos mediar com eles, era necessário incentivar também a experiência de circular e conhecer a própria UERJ, 
suas instalações, espaços, cursos, palestras, movimentos estudantis etc.

Começamos a primeira aula com apresentações e com a pergunta: "Por que escolheram estudar Pedagogia?" Frente à interessante variedade de respostas, percebemos que muitos alunos, na hora de responder, narraram histórias da sua infância, lembraram de professores e do tempo em que eles eram estudantes do ensino básico, para justificar a escolha pelo curso de Pedagogia. Ver e ouvir os alunos "lembrando ao narrar" já trouxe, de certa maneira, a inspiração para uma produção de uma Visual Storytelling no Instagram, a primeira proposta e ato de currículo que desenvolvemos juntos, na semana seguinte ao começo das aulas.

\section{Visual Storytelling no Instagram: o mergulho nas imagens da escola}

Mergulhar em imagens e lembranças é, de algum modo, viajar e reviver o passado. Em cada viagem que fazemos, nossa memória escolhe trazer coisas diferentes, constrói, reconstrói e reinventa. Nenhuma história será igual porque os contextos e as intenções do narrador mudam. 0 que acontece quando olhamos para uma fotografia da época da escola? Aprendemos alguma coisa quando contamos essas histórias? O que nos forma nessa experiência de lembrar e narrar o lembrado? E, ainda: o que acontece quando as histórias são compartilhadas em redes sociais?

A proposta de trazer a memória escolar por meio de imagens fotográficas teve uma dupla intenção: primeiro conhecer nossos praticantes culturais - as histórias que eles traziam, de onde vinham e como essas histórias os formavam; e, em segundo lugar, vivenciar um ato de currículo que integre esse movimento de lembrar e narrar em redes sociais, potencia- lizando o compartilhamento de narrativas de formação em rede.

Escolhemos o Instagram como espaço multirreferencial de aprendizagem porque é uma rede social na qual as pessoas criam, partilham e divulgam suas autorias em imagens e histórias, convertendo-se assim em um espaço propício e instigante para criação de uma Visual Storytelling. Segundo Santos (2014), o conceito de multirreferencialidade, elaborado por Ardoino (1998), dentre outros:

[...] é pertinente para contemplar nos espaços de aprendizagem uma "leitura plural de seus objetos (práticos ou teóricos), sob diferentes pontos de vista, que implicam tanto visões específicas quanto linguagens apropriadas às descrições exigidas, em função de sistemas de referenciais distintos, considerados, reconhecidos explicitamente como não redutiveis uns aos outros, ou seja, heterogêneos" (Ardoino, 1998, p.24) [...] Os sujeitos que vivem e interagem nos espaços multirreferenciais de aprendizagem expressam na escola insatisfações profundas, pondo em xeque o currículo fragmentado, legitimando inclusive espaços diversos, que há bem pouco tempo não gozavam do status de espaços de aprendizagem - através da autoria dos saberes construídos pela itinerância dos processos. [...] Para que a diversidade de linguagens, produções e experiências de vida sejam de fato contempladas de forma multirreferencializada, nos e pelos espaços de aprendizagem, os saberes precisam ganhar visibilidade e mobilidade coletiva, ou seja, os sujeitos do conhecimento precisam ter sua alteridade reconhecida, sentindo-se implicados numa produção coletiva, dinâmica e interativa que rompa com os limites do tempo e do espaço geográfico. Para tanto, as novas tecnologias e a cibercultura com sua diversidade de fenômenos poderão estruturar novas práticas de pesquisa-formação multirreferenciais. (SANTOS, 2014, p. 56)

Assim, no dia combinado, os alunos levaram as suas fotografias e começamos a aula compartilhando e comentando essas imagens, em formato de fotografia impressa, o que mudou totalmente o clima na sala de aula. Todos que- 
riam ver as fotos dos outros e saber um pouco mais das histórias que elas traziam consigo. Em seguida, havíamos planejado orientar a instalação do aplicativo do Instagram nos dispositivos móveis (celulares e tablets), mas não foi necessário, pois todos nossos estudantes já eram usuários, praticantes culturais nessa rede social. Esse, aliás, é um dado muito relevante para quem busca criar um dispositivo de pesquisaformação multirreferencial na cibercultura, já que, entender os sujeitos da pesquisa como praticantes culturais que interagem e criam autorias na cultura, implica também estar em sintonia com essas práticas do cotidiano.

Após esse momento, pedimos para que eles fotografassem e editassem a fotografia impressa que, por alguma razão, tinham escoIhido trazer para o nosso encontro. Mas não foi simplesmente um processo de digitalização da fotografia. Além da edição com filtros, no rodapé da imagem, cada praticante narrou, de maneira escrita, lembranças que se associavam à imagem.

Figura 5 - Turma criando a Visual Storytelling ${ }^{9}$

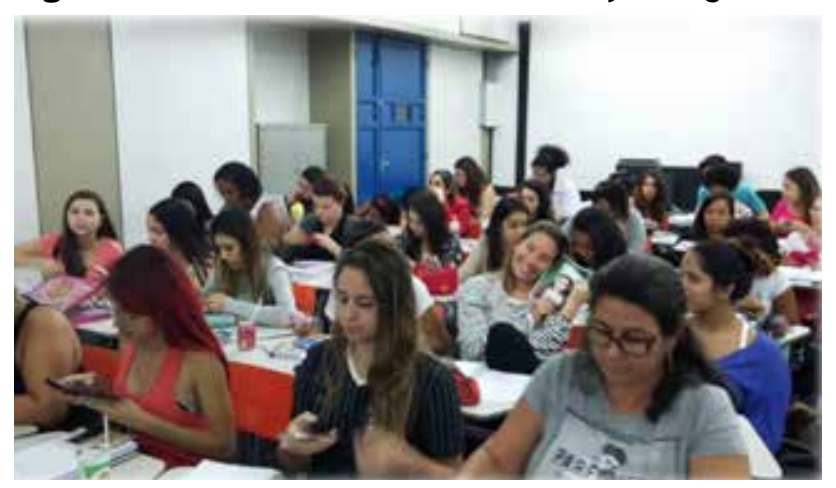

Fonte: acervo das autoras.

Para nós, a Visual Storytelling não é simplesmente uma fotografia com legenda, mas a entendemos como um todo. Um fenômeno da cibercultura que se manifesta como uma nova

9 É importante dizer que os estudantes estiveram cientes da pesquisa em formação e permitiram de forma burocrática, assinando um termo de consentimento, mas também de forma sensivel, criando uma relação de respeito e não só, também de troca de conhecimentos. forma de narrar, na qual, aliás, pode se integrar, além de imagem e narrativa, hashtags e localização geográfica no mapa do app. Todos esses elementos entram em diálogo e podem compor a narrativa. Nesse momento, em sala de aula, portanto, se potencializou um processo de narração de si, hipertextual, ligado à memória escolar de cada um.

Ver uma fotografia significou/significa, sempre, contar histórias, em narrativas sobre a situação retratada ou sobre outra que a imagem lembra, ou, ainda, sobre pesquisas que nela estão ou que, 'justamente' não estão, mas 'que dela me lembrei porque...' E, também, o sentido inverso se dá quando, narrando um fato acontecido, alguém diz: 'tenho uma fotografia ótima desse dia...' E, esquecendo o relato, se levanta para buscar, em outro cômodo, a tal fotografia que chegando, lembra uma história diferentes da que estava sendo contada. (ALVES, 2008b, p. 182)

A relação entre a imagem e o texto vem sendo por nós pouco a pouco explorada (D'ÁVILA; MADDALENA; CARVALHO, 2015), encontrando nas práticas em sala de aula e nas produções cotidianas, inclusive as on-line, diversas reflexões que não raras vezes se contradizem. Se quando entendemos que texto e imagem formam uma única composição, nos questionamos afinal quais as diferenças entre ambos. É comum recorrer à imagem de modo ilustrativo, o que não entendemos como um problema, mas observamos que a escolha e a edição da imagem se dedicam a uma ferrenha objetividade que, compreendendo as redes de formação de cada pessoa, e, ainda, o espaço e tempo em que se encontra, as interpretações e a "abruptidão" da imagem transgridem a comunicação sem impurezas.

O texto, aliás, não escapa a este jogo entre aquilo que se quer dizer e aquilo que se entende do que foi produzido. Quando, nesse caso que trouxemos, a escolha da imagem antecede a produção textual, mas não só antecede, ou 
melhor, se despreocupa do propósito objetivo de busca de uma imagem. Todos nós sabemos que um dia revolvemos nosso passado nalgum objeto velho que também carrega memórias, que esse momento, como é geralmente raro, é precioso e carregado de sentimentos e pensamentos que nos arrebatam a alma. A cada imagem que se toca, o tempo se desconecta do sistema mundial de horas, o corpo transgride a contagem de segundos, e como quem não se quer deixar, as imagens reveladas formam um fio condutor de memórias que se rasgam, exercendo o esforço de lembrar, instigando a conversa com os que (daquela época) ainda estão vivos. E, por fim, escolher, entre tantas, a que, por alguma maneira, é significativa para si mesmo, de uma maneira que é para mais ninguém.

0 recorte de um espaçotempo pede que cada detalhe de outrora seja decodificado, que, assim, ganha traços de uma imaginação fertilizada por todas as experiências éticas -estéticas criadas e vividas até então. A ficção está, assim como no texto, na imagem. A maldita ideia das professoras me fazerem caçar a mim mesma, que talvez tenha me feito chorar e rir, pôde demonstrar, em uma multiplicidade de gestos físicos, aquilo que é tão difícil de se definir: as iconicidades que a visualidade propõe, desde que a humanidade se fez.

Por vezes, questionamos a presença da legenda nas imagens que nos acompanham em pesquisa, porém, tão libertador quanto a imagem só é o complexo performático que se forma quando acrescentamos outros elementos ao sistema linguístico. Este último, ingenuamente, se propõe a versar nos limites gramáticos, mas, sabem bem os que trabalham com leis, que não existe um texto desprevenido de brechas.

Na narração de uma história pessoal, vários elementos entram em jogo. Não se trata somente de nossas lembranças do passado, mas também de uma tessitura ligada ao con- texto (atual) do nosso presente. Para quem narramos? Com que intenção? Que histórias decidimos contar e por quê? A ensaísta argentina Beatriz Sarlo, no seu livro Tempo passado: cultura da memória e guinada subjetiva (2007), apresenta um levantamento interessante concernente às relações entre memória, experiência e construção do testemunho nas narrativas pessoais. A autora sustenta que "o tempo próprio da lembrança é o presente: isto é, o único tempo apropriado para lembrar e, também, o tempo do qual a lembrança se apodera, tornando-o próprio" (SARLO, 2007, p. 10). A lembrança, assim como o cheiro, vem para a nossa memória mesmo quando não é convocada e, quando narrada, não fala só do passado, mas também se refere ao presente.

A lembrança não permite ser deslocada e, de alguma maneira, precisamos dela para relatar nosso presente. Essas "visões do passado" são construções, pois falamos do passado sem suspender o presente e, muitas vezes, fazendo referência ao futuro. Segundo Sarlo (2007, p. 48-49),

O presente da enunciação é o tempo de base do discurso, porque é presente o momento de se começar a narrar e esse momento fica inscrito na narração. [...] Isso implica que nos relatos testemunhais encontremos um narrador implicado nos fatos, já que os tempos verbais do passado não ficam livres do tempo presente da enunciação.

Para a autora, é inevitável desconsiderar o presente no ato de narrar uma história pessoal, já que as interferências do próprio tempo, o contexto e as práticas do cotidiano são marcantes no consciente e no inconsciente de cada narrador. Nesta linha de pensamento, a autora afirma que as narrativas testemunhais são contornáveis no presente. É o presente que, em um jogo contínuo com a memória, mostra as questões que queremos enfatizar ou não. 
Ao narrar-se, a pessoa parte dos sentidos, significados e representações que são relacionados às experiências vividas e mesclados à própria experiência do momento. A arte de narrar, como uma contação de si, instaura-se num processo metanarrativo, porque expressa o que ficou na sua memória (SOUZA, 2006). A memória gira em torno da relação passado-presente e traz consigo um complexo processo de transformação das experiências relembradas, pois, quando narradas, sempre mudam. "Que memórias escolhemos para recordar e relatar (e portanto, relembrar) e como damos sentido a elas são coisas que mudam com o passar do tempo" (THOMSON, 1997, p. 57). Ao dizer uma história, eu a faço e sou um narradorpraticante dos relatos que chegam até mim, neles inserindo o fio do meu modo de contar (ALVES, 2008a, p. 33).

Tempo, memória e esquecimento. Uma triologia para pensar a arte de lembrar, para estruturar um olhar sobre si, para revelar-se. A memória é escrita num tempo, um tempo que permite deslocamento sobre experiências. Tempo e memória que possibilitam conexões com as lembranças e esquecimentos de si, dos lugares, das pessoas, da família, da escola e das dimensões existenciais do sujeito narrador. (SOUZA, 2006, p. 102-103)
É assim que construímos e reconstruímos nossos eus, constantemente, frente a cada situação com que nos deparamos. A triologia tempo, memória e esquecimento formam parte desse processo e a "arte de lembrar" (SOUZA, 2006) é fundamental na hora de escrever ou contar uma narrativa. Uma história que contamos para a mesma pessoa, em uma segunda oportunidade, pode ser diferente da primeira vez que a narramos. Por que isto acontece?

Segundo Bruner (2014, p. 74), fazemos isso constantemente, com a orientação das nossas memórias do passado e de nossas esperanças no futuro. Mas, diferentemente de Sarlo, Bruner traz um componente interessante ao debate sobre a construção do eu, sustentando que "a testemunha ocular e os vívidos flashes de memória servem a muitos mestres, não apenas à verdade" (BRUNER, 2014, p. 32), fazendo alusão à fabricação de histórias nesse processo de narrar. $O$ autor sustenta que, na construção do eu, há um ato criativo, uma fabricação e invenção de histórias. A "verdade" do que é narrado é totalmente subjetiva, não havendo uma verdade e, sim, uma invenção.

Figura 6 - Visual Storytelling de Lúcia
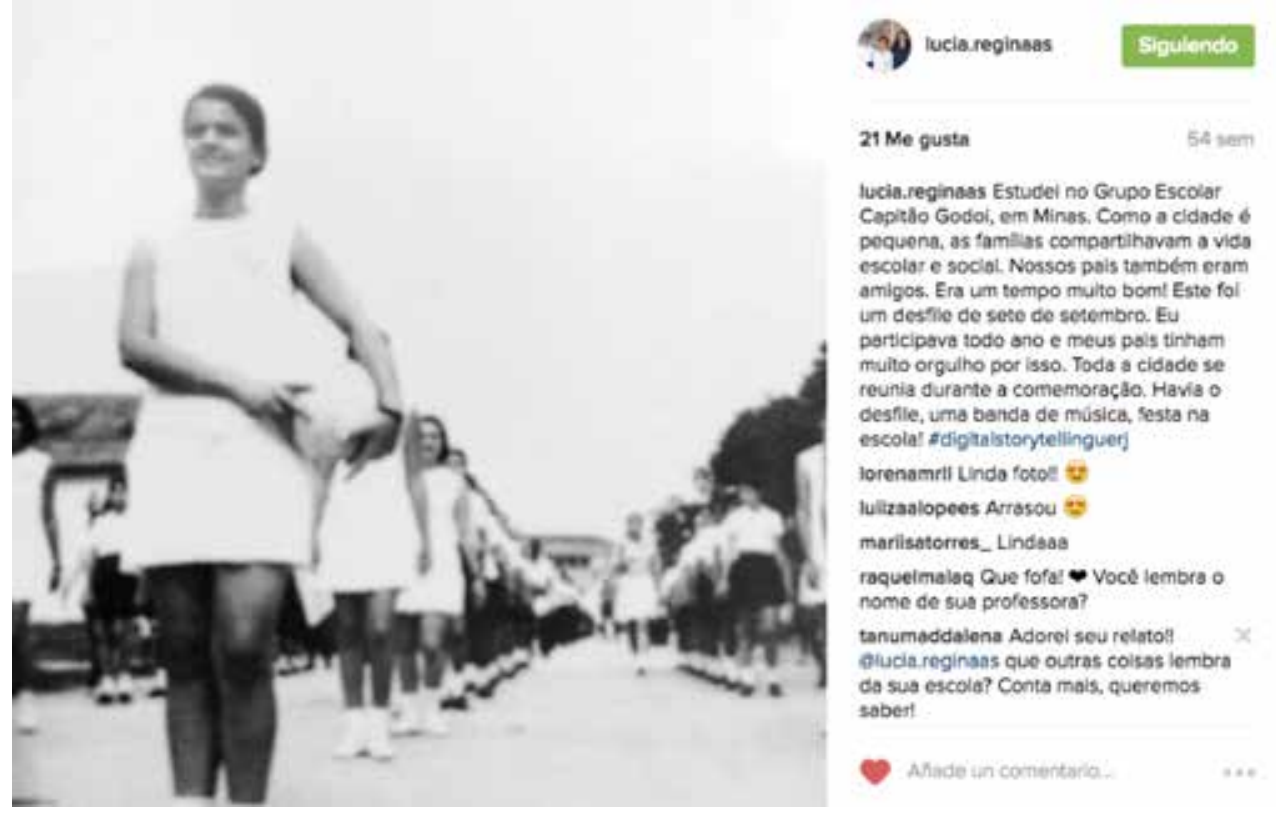

Fonte: Instagram. 
Nessa Visual Storytelling criada pela estudante Lúcia (Figura 6), podemos observar como o acontecimento do desfile da escola, no dia 7 de setembro, narrado na fotografia cobrou significado. A imagem do desfile traz a lembrança da sua família e da cidade natal, em Minas Gerais, que se reunia em torno à co- memoração. Aqui temos a escola tradicional e seus dispositivos de formação cidadã sendo narrados. Lúcia não foi a única aluna que lembrou do desfile do 7 de setembro, Letícia (Figura 7) também trouxe a lembrança do mesmo dia, com outro artefato significativo da cultura escolar: a bandeira.
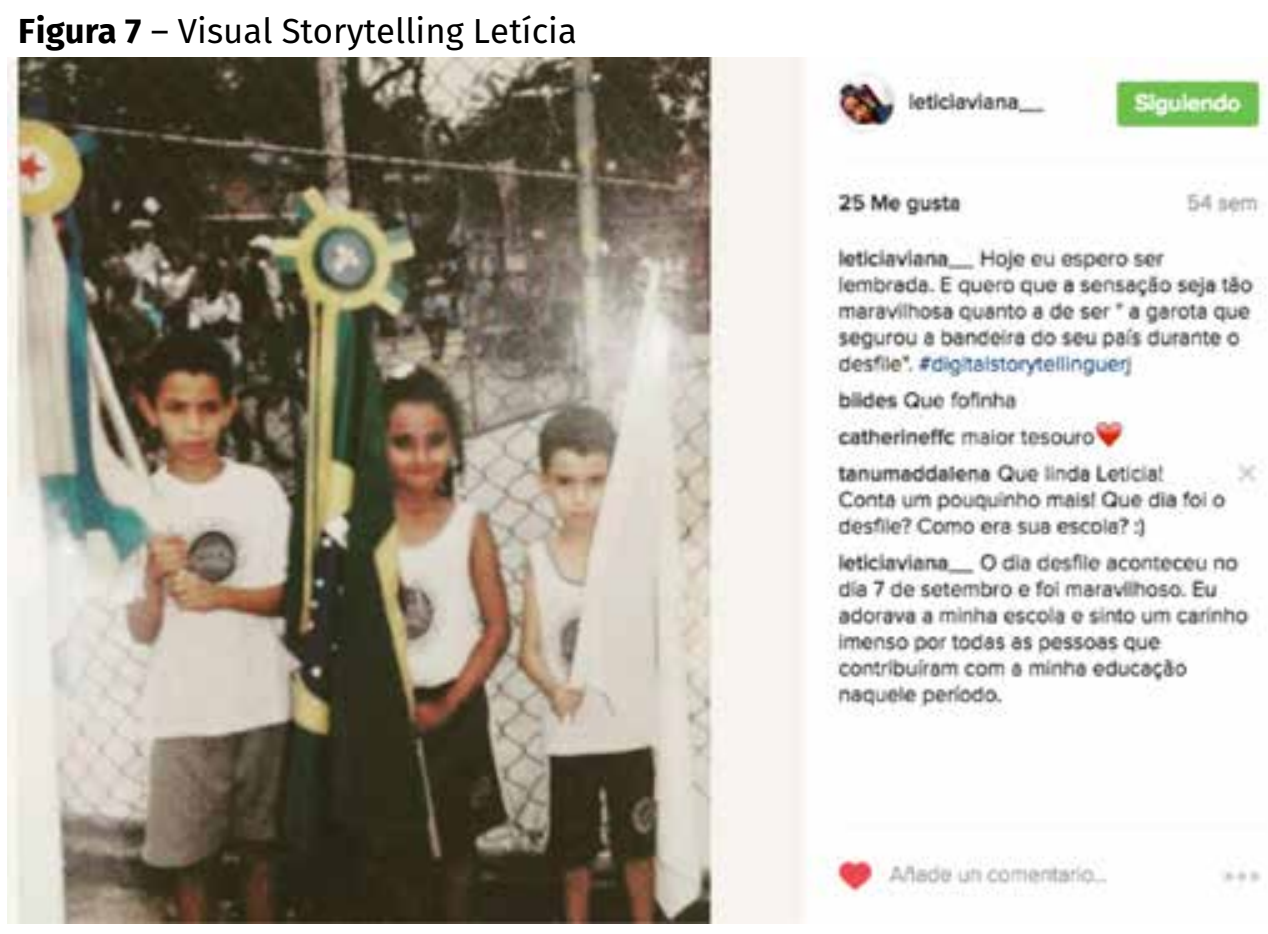

Fonte: Instagram.

A maneira como queremos "ser lembrados" está implícita na forma em que narramos essas lembranças. A participação nos atos escolares, nos desfiles, a roupa que foi utilizada na festa junina, a decoração da escola, seus espaços e cheiros. Todos esses detalhes formam e compõem os "acontecimentos", que são evocados na hora de olhar para as imagens fotográficas, que atuam como "personagens conceituais" (ALVES, 2015, p.216) no sentido de dialogar e trazer pistas valiosas sobre as ideias e valores das práticas pedagógicas cotidianas que os praticantespensantes viveram nesses momentos.

Pedimos, então, para que cada Visual Storytelling fosse compartilhada no Instagram com a hashtag \#DigitalStorytellingUERJ, para assim poder ter o acesso a todas fotografias e criações dos estudantes.
Muitos comentários nas fotos dos praticantes foram surgindo, na rede social, após o compartilhamento. E aqui habita uma das maiores potencialidades da Storytelling, em tempos de cibercultura: o compartilhar histórias de vida e formação de maneira pública, nas redes sociais. Esse ato possui um caráter formativo e, ao mesmo tempo em que a narrativa é compartilhada, as trocas e comentários disparam novas lembranças e novas narrativas digitais de si.

Aprendemos com Macedo (2016) que a heteroformação, como formação com o outro, é um dos elementos que compõe e integra a visão plural do processo formativo. Assim, a maior potência do acontecimento e da experiência formativa, quando são narrados na hipermídia, é que supõem a alteridade, desde a 
sua concepção, pois, quando escrevemos em ambientes digitais, a escrita é pública. Seja no Blog, no Facebook, na imagem do Instagram, no vídeo do Youtube, o que está escrito impli- ca, sempre, um leitor, um outro que me lê, responde, comenta, cocria minha mensagem. Isso não é menor, nem no alcance, nem nas questões formativas que esse fato implica.

Figura 8 - \#DigitalStorytellingUERJ

\section{\#digitalstorytellinguerj \\ 30 publicaciones}

PUBLICACIONES DESTACADAS
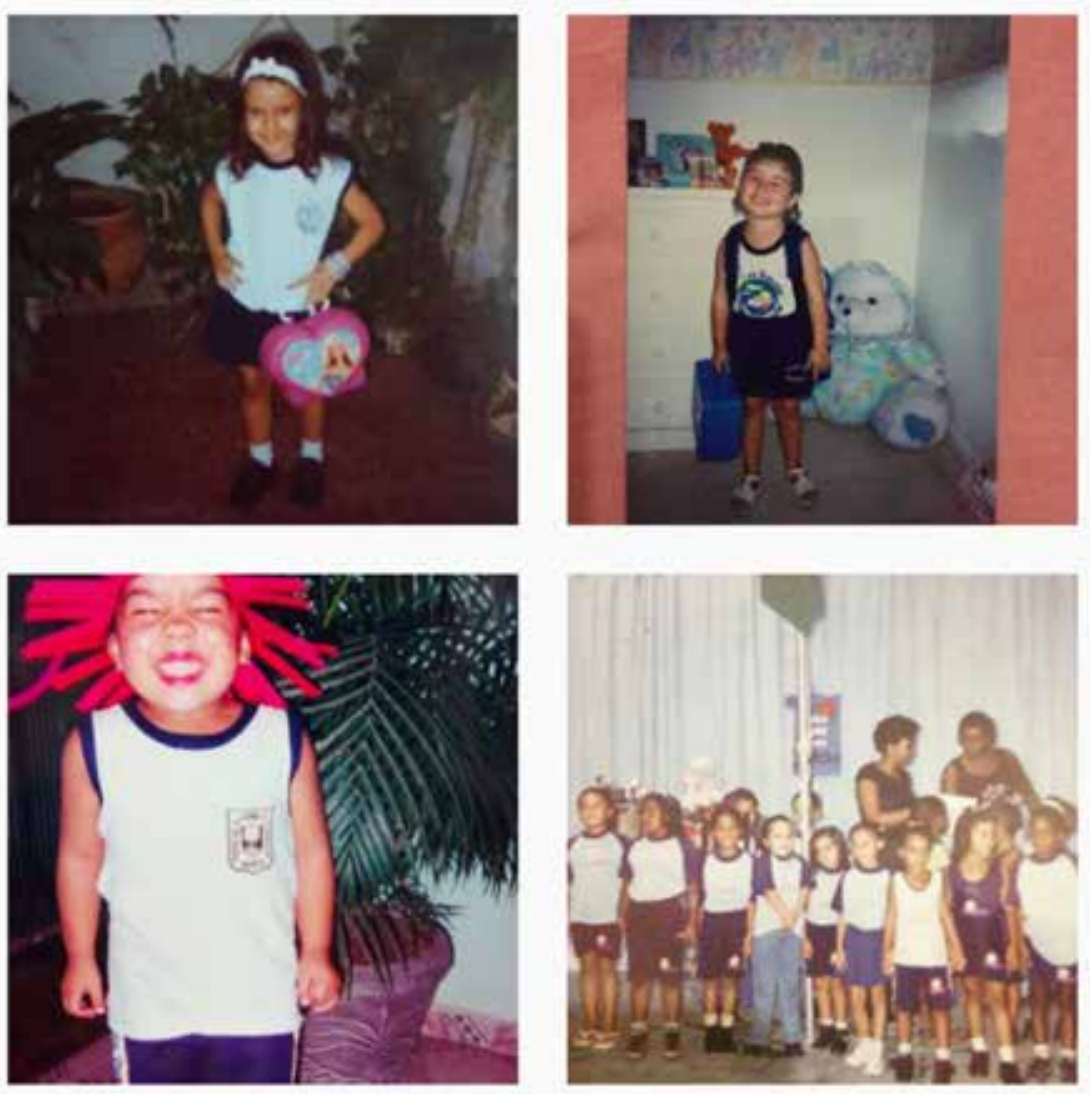
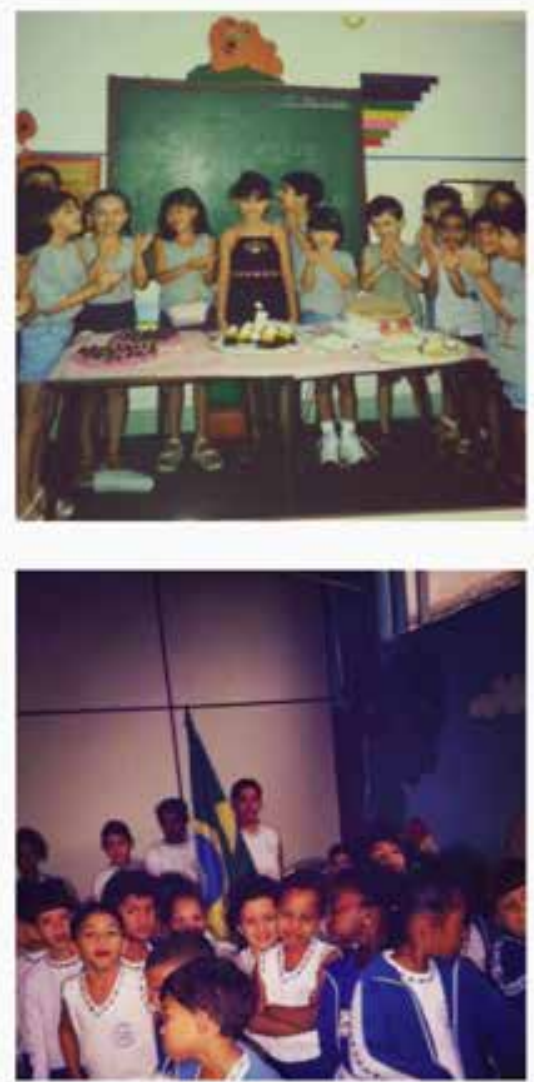

Fonte: Instagram.

A maneira como escrevemos publicamente não é a mesma de quando escrevemos para nós mesmos, num espaço íntimo. Ao compartilhar uma foto ou narrativa, em uma rede social, o fazemos com a intenção de que o outro possa ler, curtir, comentar e compartilhar. A alteridade está presente, desde o início, na narração de uma história, pois o outro também a compõe.

\section{"Eu lembro de cada detalhe"}

Ao longo da pesquisa, bebemos nas investigações autobiográficas/experienciais o conceito de "escrita de si" (JOSSO, 2004; SOUZA, 2006) e o trabalho que estas pesquisas desenvolvem com a utilização da escrita como um dispositivo de auto-conhecimento, possibilitando, por meio da escrita, um "mergulho interior" pelo qual dotamos de sentido as experiências vividas. Seguindo esta linha teórica, somamos ao conceito de "escrita de si" o prefixo "hiper". Entendemos por hiperescritas, práticas culturais de escrita na hipermídia, sempre dando prioridade a um tipo de escrita digital que possui como base a contação de histórias, sejam his- 
tórias de vida, ficções ou invenções. Para nós, as hiperescritas estão fundadas no hipertexto, fazem uso dele e o incorporam, combinando outros elementos digitais. (imagens, sons, hiperlinks, vídeos etc.)

Figura 9 - Visual Storytelling de Monique
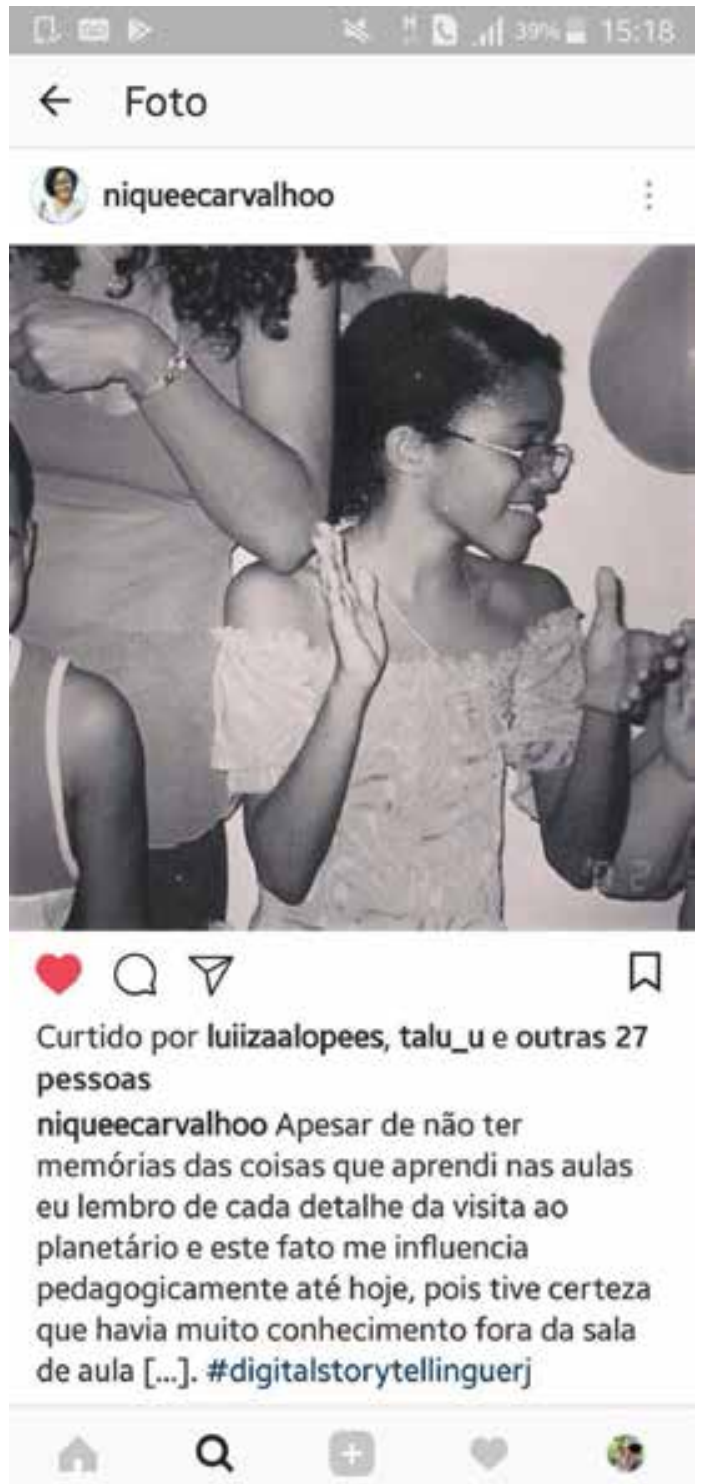

Fonte: Instagram.

A possibilidade de combinar texto e outros tipos de signos, em hiperambientes, descentraliza a hierarquia linear e reconceitualiza a dimensão gráfica do texto. Por isso se fala em hiperescrito, hiperficção, hiperconto, hiperpoesia, hiperedição etc. (SANTAELLA, 2013, p. 215). Nos inspiramos nesses conceitos para falar de "hiperescritas de si", em nossa experiência com a criação de Visual Storytelling.
Então, o que são as hiperescritas de si? São as escritas que contêm experiências, lembranças, relatos e ficções sobre si mesmo e o processo formativo, na linguagem da hipermídia. Ou seja, que utilizam e expandem a plasticidade do digital e suas possibilidades imagéticas, de hiperlinks e espaço/temporais das redes, para contar histórias de vida, inventá-las e ficcionalizar a própria vida.

A fotografia de Monique pode ser de um outro evento da infância, que não seja a visita ao planetário, mas, na sua hiperescrita de si, ela trouxe esses elementos para compor sua invenção que, de alguma maneira a influenciam até hoje. " - Eu lembro de cada detalhe da visita ao planetário e este fato me influencia pedagogicamente até hoje, pois tive certeza que havia muito conhecimento fora da sala de aula". Os espaçotempos escolares, o dentrofora da escola e as potencialidades de aprendizagem nas diversas redes educativas pelas quais transitamos na infância; o peso da memória escolar no hoje, imagem e escrita juntas, compondo a narrativa, a hiperescrita de si em rede.

Assim, nossa ciberpesquisa-formação buscou inspiração nas práticas culturais e nos fenômenos que acontecem na cultura para aprenderensinar junto aos praticantespensantes da pesquisa. Para nosso olhar cotidiano e multirreferencial, são essas práticas do dia a dia que nos formam e transformam. As conversas e trocas nos diversos espaçostempos que habitamos, os artefatos culturais com que interagimos e construímos autorias, criações que falam da relação que temos com nosso contexto e com o mundo.

Por isso, fizemos este investimento em rastrear o fenômeno da Storytelling na atualidade, já que consideramos que narrar o cotidiano, a vida, a formação, hoje, pode ser feito por meio de uma multiplicidade de linguagens que a hipermídia nos propicia. Mas não conta- 
mos só com outras mídias, mas também com outras interfaces que possuem o compartilhamento como um dos principais caracteres que forma inclusive a nossa contemporaneidade. Lembrar em coletivo, alongando o espaçotempo de como e onde isso é feito, promove uma nova forma de lembrar e contar histórias. Os detalhes, mesmo que agora registrados sem a poeira fisica, mas a poeira virtual, ainda que tão nítidos em nossa memória, que se estende para as nuvens, retomam sempre a abertura da ressignificação. Assim é, pois, inclusive, quando nos tornamos professoras, retornamos àquele espaçotempo tão vivo de lembranças, seja até mesmo na ausência delas, como Monique conta.

Talvez nessa disciplina antecipamos esse retorno, mas com uma curva diferenciada, não só porque ainda eram graduandos, mas porque ao carregar em sala de aula e depois na nuvem a sua memória e suas reflexões que esta excitou, há um retorno coevo daqueles que olham, lêem, sentem aquele material tão íntimo e sensivel de um passado-presente compartilhado. 0 trazer-se à tona, tornar-se autor de sua própria encenação, é também visto por nós como um processo de aprendizagem necessário a encarnações outras desse ser ciber -autor, curioso criador das linhas e das entrelinhas de si, e de nossa história coletiva.

\section{Referências}

ALVES, Nilda. Decifrando o pergaminho - os cotidianos das escolas nas lógicas das redes cotidianas. In: OLIVEIRA, Inês Barbosa de; ALVES, Nilda. (Orgs.). Pesquisa nos/dos/com os cotidianos das escolas: sobre redes de saberes. 3. ed. Petrópolis, RJ: DP\&A, 2008a. p. 15-38.

ALVES, Nilda. Lembranças em imagens. In: PASSEGGI, Maria da Conceição; BARBOSA, Tatyana Mabel Nobre. Narrativas de formação e saberes biográficos. Natal: Ed. Da UFRN, 2008b. p.175-195.

ALVES, NILDA. Faz bem trabalhar a memória: criação de currículos nos cotidianos, em imagens e narrativas. In: GARCIA, Alexandra; OLIVEIRA, Inês Barbosa de. (Orgs.). Nilda Alves: praticantepensante de cotidianos. Belo Horizonte: Autêntica Editora, 2015. p. 207-217.

ARDOINO, Jacques. Abordagem multirreferencia (plural) das situações educativas e formativas. In: BARBOSA, J. (Org.). Multirreferencialidade nas ciências e na educação. São Carlos: EDUFScar, 1998.

BRUNER, Jerome. Realidad mental y mundos posibles. Barcelona: Gedisa, 1998.

BRUNER, Jerome. Fabricando histórias: direito, literatura, vida. São Paulo: Letra e Voz, 2014.

CERTEAU, Michel de. A invenção do cotidiano: artes de fazer. 19. ed. Tradução de Ephraim Ferreira Alves. Petrópolis, RJ: Vozes, 2012.

D'ÁVILA, Cristina. Formação docente na contemporaneidade: limites e desafios. Revista da FAEEBA: Educação e Contemporaneidade, Salvador, v. 17, n. 30, p. 33-43, jul./dez. 2008.

D’ÁVILA, Carina; MAdDALENA, Tania; CARVALHO, Felipe. Imagens voláteis e Digital Storytelling: novas práticas pedagógicas na cibercultura. In: PORTO et al. (Orgs.). Pesquisa e mobilidade na cibercultura: itinerâncias docentes. Salvador: Edufba, 2015.

JOSSO, Marie-Christine. Experiências de vida e formação. São Paulo: Cortez, 2004.

MACEDO, Roberto Sidnei. Outras luzes: um rigor intercrítico para uma etnopesquisa política. In: MACEDO, Roberto Sidnei; GALEFFI, Dante; PIMENTE Álamo. (Orgs.). Um rigor outro: sobre a questão de qualidade na pesquisa qualitativa. Salvador: Edufba, 2009. p. 75-126.

MACEDO, Roberto Sidnei. A pesquisa e o acontecimento: compreender situações, experiências e saberes acontecimentais. Salvador: Edufba, 2016.

NÓVOA, Antônio. Prefácio. In: JOSSO, M.C. Experiências de vida e formação. São Paulo: Cortez, 2004. p. 11-34.

OLIVEIRA, Inês Barbosa de. Currículos e pesquisas com os cotidianos: o carácter emancipatório 
dos currículos "pensadospraticados" pelos "praticantespensantes" dos cotidianos das escolas. In: FERRAÇO, Carlos Eduardo; CARVALHO, Janere MagaIhães. (Orgs.). Curriculos, pesquisas, conhecimentos e produções de subjetividades. Petrópolis, RJ: PDetAlli, 2012. p. 47-70.

SANTAELLA, Lucia. Comunicação ubíqua. Repercuções na cultura e na educação. São Paulo: Paulus, 2013.

SANTOS, Edméa. Pesquisa-formação na cibercultura. Santo Tirso, Portugal: Whitebooks, 2014.

SARLO, Beatriz. Tempo passado: cultura da memória e guinada subjetiva. São Paulo: Cia. das Letras; Belo Horizonte: UFMG, 2007.

SOUZA, Elizeu. Clementino de. Pesquisa narrativa e escrita (auto)biográfica: interfaces metodológicas e formativas. In: SOUZA, E. C.; BARRETO, A. M. Tempos, narrativas e ficções: a invenção de si. Porto Alegre: EDIPUCRS, 2006. p. 135-147.

THOMSON, Alistair. Recompondo a memória - questões sobre a relação entre a história oral e as memórias. Projeto História: Revista do Programa de Pós-graduados de história. São Paulo, v.15, n. 2, p. 51-84, abr. 1997. Disponivel em: <https://revistas.pucsp.br/index.php/revph/article/view/11216>. Acesso em: 15 jun. 2017.

XAVIER, Adilson. Storytelling. Histórias que deixam marcas. Rio de Janeiro: BestBusiness, 2015.

Recebido em: 10.08.2017

Aprovado em: 20.12.2017

Tania Lucia Maddalena é Doutora em Educação pelo Proped/UERJ, membro do Grupo de Pesquisa Docência e Cibercultura (GPDOC/UERJ). Mestre em Educação (UNICAMP), Especialista em Educação e Novas Tecnologias (FLACSO/Argentina) e Bacharel em Ciências da Educação (UNLP/Argentina).e-mail: tlmaddalena@gmail.com

Faculdade de Educação/UERJ. Rua São Francisco Xavier, no 524, Grupo 12.037-F, Rio de Janeiro. CEP: 20550-013. (21) 996724771

Carina d'Ávila é Mestre em Educação pelo Proped/UERJ, membro do Grupo de Pesquisa Docência e Cibercultura (GPDOC/UERJ) e bolsista PCI/CNPQ no Museu de Astronomia e Ciências Afins. e-mail: carinandavila@gmail.com

Faculdade de Educação/UERJ. Rua São Francisco Xavier, no 524, Grupo 12.037-F, Rio de Janeiro. CEP: 20550-013. (21) 987181286

Edméa Santos é Doutora em Educação pela Universidade Federal da Bahia. Pós-doutorada em Educação pela Universidade Aberta de Lisboa. Professora adjunta da Faculdade de Educação da Universidade do Estado do Rio de Janeiro (UERJ). Atua no Programa de Pós-Graduação em Educação (ProPEd) da UERJ. Líder do GPDOC, Grupo de Pesquisa Docência e Cibercultura do ProPEd/UERJ. e-mail: edmeabaiana@gmail.com

Faculdade de Educação/UERJ. Rua São Francisco Xavier, no 524, Grupo 12.037-F, Rio de Janeiro. CEP: 20550-013. (21) 996212804 